\title{
First record of Conura (Conura) maculata (Fabricius, 1787) (Hymenoptera, Chalcididae) parasitizing Opsiphanes invirae amplificatus Stichel, 1904 (Lepidoptera, Nymphalidae) in the province of Corrientes, Argentina
}

\author{
Paula Belén Gervazoni ${ }^{1}$, Manuel Osvaldo Arbino ${ }^{2}$ \\ 1 Centro de Ecología Aplicada del Litoral (CECOAL-CONICET-UNNE) Ruta 5, km 2.5, (3400), Corrientes, Argentina. 2 Universidad Nacional \\ del Nordeste, Facultad de Ciencias Exactas y Naturales y Agrimensura, Departamento de Biología, Laboratorio Biología de los Invertebrados, Av. \\ Libertad 5470, Corrientes, Argentina. \\ Corresponding author: Paula Belen Gervazoni paulabelengerv@gmail.com
}

\begin{abstract}
We report the first record of Conura (Conura) maculata (Fabricius, 1787) in the province of Corrientes, Argentina. A total of 85 adult wasps of $C$. maculata were obtained from 3 chrysalides of Opsiphanes invirae amplificatus Stichel, 1904, a lepidopteran pest of native and exotic palm trees. This is the first report of the occurrence of this parasitoid in the province of Corrientes, extending this species' known distribution in the country. This is also the first report of the parasitoid-host interaction between these 2 species for Argentina.
\end{abstract}

Key words

Chalcidoidea; natural enemy; palms; parasitoids wasps.

Academic editor: Gabriela P. Camacho | Received 10 April 2018 | Accepted 18 September 2018 | Published 21 December 2018

Citation: Gervazoni PB, Arbino MO (2018) First record of Conura (Conura) maculata (Fabricius, 1787) (Hymenoptera, Chalcididae) parasitizing Opsiphanes invirae amplificatus Stichel, 1904 (Lepidoptera, Nymphalidae) in the province of Corrientes, Argentina. Check List 14 (6): $1155-1159$. https://doi.org/10.15560/14.6.1155

\section{Introduction}

The parasitoids can be considered key species for maintaining communities' equilibrium by functioning as regulators of the population density of other insects (Stireman and Singer 2003, Nájera and Souza 2010). The majority of the Chalcididae are primarily parasitoids of Lepidoptera, Diptera, and Coleoptera, while some parasitize species in other insect orders, such as Hymenoptera and Neuroptera, and others are hyperparasitoids (Gibson 1993, De Santis 1989, Gates et al. 2012). The family has a worldwide distribution with 1,464 species in 87 genera (Noyes 2017). The Neotropical fauna is represented by
217 species (Delvare and Arias-Penna 2006) of which 63 have been reported in Argentina (Noyes 2017), where the genus Conura Spinola, 1837 is the best represented, with 30 species (Noyes 2017). Conura are generally parasitoids of both larval and pupal stages of lepidopteran (Marchiori et al. 2004, Marcicano et al. 2007, SalgadoNeto and Lopes da Silva 2011, Tibcherani et al. 2016), but also parasitize larvae of Diptera and other Hymenoptera (Stireman and Singer 2003, Couri et al. 2006), Coleoptera (Montes and Costa 2011), and Neuroptera, or are hyperparasitoids of Icneumonidae and Tachinidae (Couri et al. 2006, Sakazaki et al. 2011). They are usually 

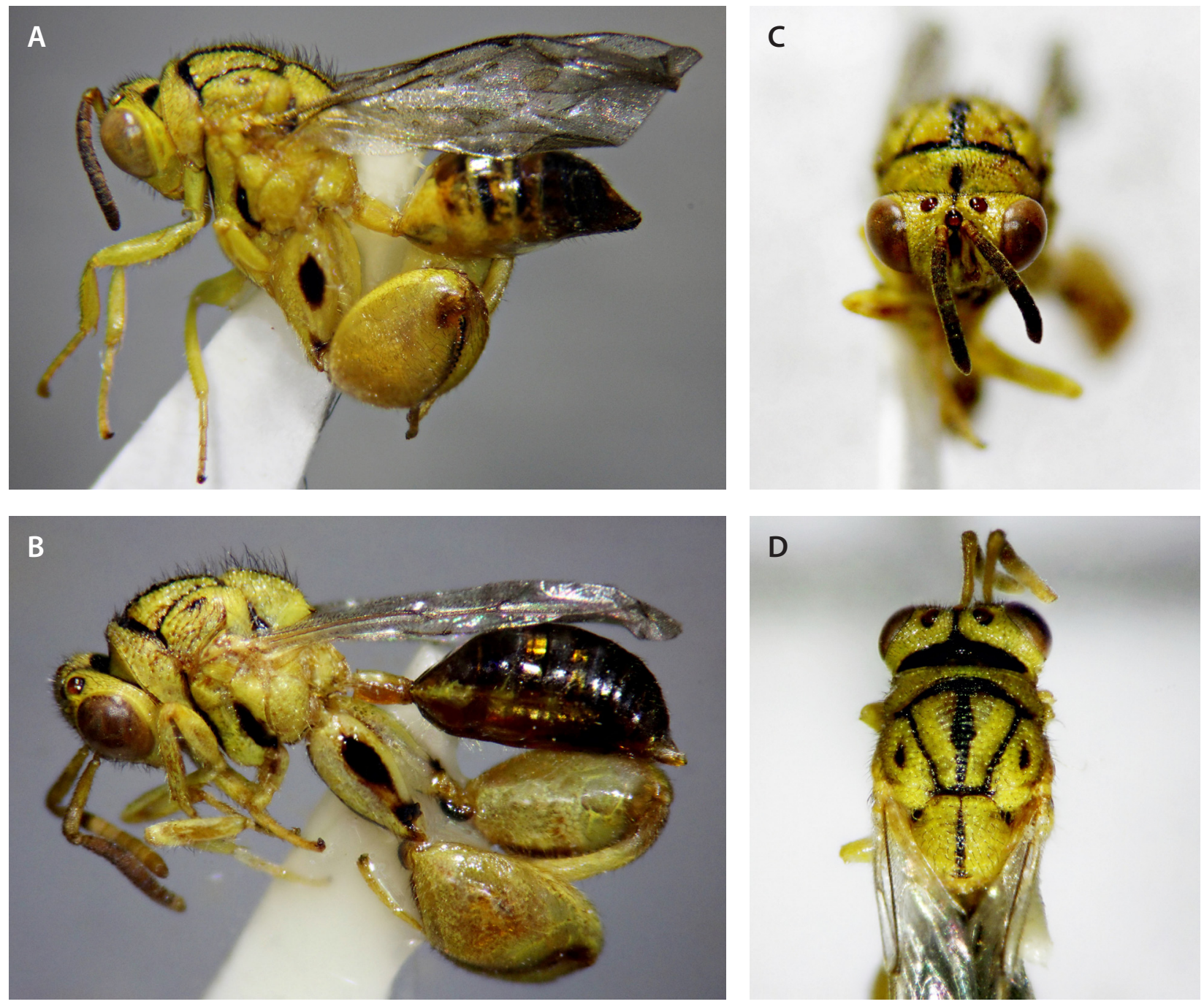

Figure 1. Specimens of C. maculata from Corrientes, Argentina. A. Female lateral view. B. Male lateral view. C. Head, frontal view. D. Thorax, dorsal view.

solitary parasitoids, but some smaller species are gregarious (Gates et al. 2012).

Conura maculata (Fabricius, 1787) is a gregarious parasitoid, currently known to occur in North America (USA and Mexico), Central America (Nicaragua, Panama, and Costa Rica) and South America (Venezuela, Colombia, French Guiana, Ecuador, Paraguay, Brazil, and Argentina) (De Santis and Fidalgo 1994, Salgado-Neto and Lopes da Silva 2011, Arias and Delvare 2003, Noyes 2017).

Opsiphanes invirae (Hübner, [1808]) is a lepidopteran of the family Nymphalidae. In some South American Countries, it is considered a pest of plants of economic interest, like bananas (Musaceae) (Pulido and Cardenas 1979), the açaí palm (Euterpe oleraceae), the oil palm (Elaeis guineensis), and the coconut (Cocos nucifera) (Salgado Neto 2013, Ferreira et al. 2015, Brandão et al. 2017). In Argentina, O. invirae amplificatus Stichel, 1904 is widely distributed in the central-northeastern provinces (Hayward 1973, Núñez Bustos 2008) and has been reported causing damage to native and exotic palms (Pastrana and Braun 2004). It is considered among the 3 most problematic insects for palms in the province of Buenos Aires (Márquez and Florentino 2007).
Conura maculata has been reported acting as a natural enemy of $O$. invirae amplificatus by Salgado-Neto and Lopez da Silva (2011) in Brazil. Here, we report for the first time the occurrence of this parasitoid in the province of Corrientes. Our new record extends the known distribution of this species in Argentina and expands the known distribution of the host-parazitoid interaction between $C$. maculata and $O$. invirae amplificatus to the province of Corrientes.

\section{Methods}

We sampled in an urban area near the campus of the Universidad Nacional del Nordeste, Corrientes city, province of Corrientes, Argentina (Fig 1). Between June 2013 and April 2014, we collected chrysalides of $O$. invirae amplificatus from Syagrus romanzoffiana (Cham.) Glassman stipes, house lintels, and external walls of buildings. Chrysalids were carefully removed, placed in plastic containers, and transported to the Laboratorio Biología de los Invertebrados. They were isolated in the lab and each chrysalid was hung by the cremaster with a thread inside cellophane paper bags $(30 \mathrm{~cm} \times 25 \mathrm{~cm})$ with microperfo- 


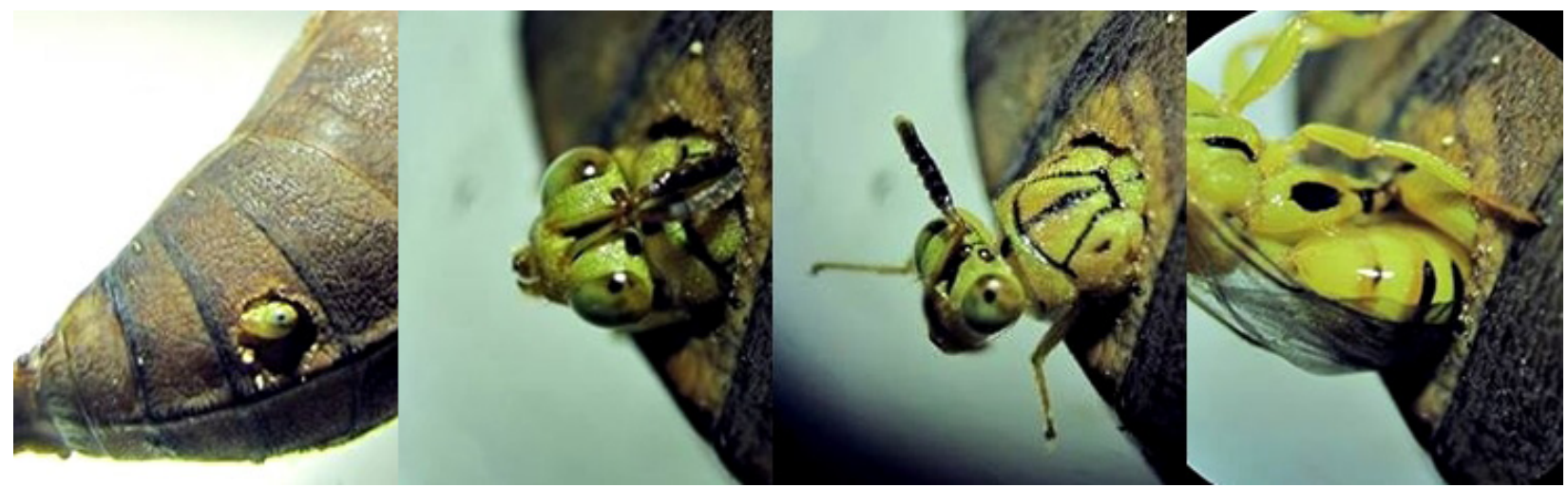

Figure 2. Specimen of Conura maculata from Corrientes emerging from a pupae of Opsiphanes invirae amplificatus in the laboratory.

rations. The chrysalids were kept under light-controlled conditions (equal amounts of light and darkness in a 24 $\mathrm{h}$ period) and natural temperature and humidity. The chrysalids were observed daily until the emergence of the butterfly or the parasitoids. Some parasitoids obtained were kept in $80 \%$ ethanol while others were mounted on entomological pins. We recorded the number of individuals and sex ratio of the emerged parasitoids.

Adults of $C$. maculata were identified based on the species redescriptions by Boucek and Delvare (1992) and Salgado-Neto (2008). Our identitification was confirmed by the group's specialist, Dr Gerard Delvare, (Centre de cooperation Internationale en Recherche Agronomique pour le Développement, Montpellier, France). The chrysalides and adult lepidopteran were identified based on Bristow (1991), Salgado-Neto (2008), and Canals (2003). The wasp's geographic distribution in South America was obtained from published data (De Santis and Fidalgo 1994, Salgado-Neto and Lopes da Silva 2011, Arias and Delvare 2003, Noyes 2017), and the map was designed using Quantum GIS v. 2.18.14 (datum WGS84).

All the material was deposited in the collection of the Universidad Nacional del Nordeste, Facultad de Ciencias Exactas, Naturales y Agrimensura, Corrientes, Corrientes, Argentina (CARTROUNNE).

\section{Results}

We randomly collected 21 chrysalids of $O$. invirae amplificatus. Thirteen emerged as adults, 5 died, and 3 were wild-caught parasitized (Cp). From the latter, 70 adult females and 15 adult males of C. maculata emerged (C1p:

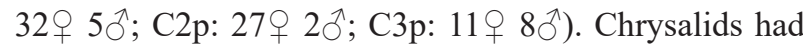
an average of 3 perforations each made by the eruption of parasitoids. We observed that an adult of C. maculata emerges from the host through a circular opening (Fig. 2 ), which could be made with its mandibles or by taking advantage of a perforation already made by another individual.

\section{Conura maculata (Fabricius, 1787)}

Material examined. Argentina: Corrientes: city of Corrientes: Barrio Universitario $\left(27^{\circ} 27^{\prime} 51^{\prime \prime} \mathrm{S}, 058^{\circ} 46^{\prime} 51^{\prime \prime} \mathrm{W}\right.$, $52 \mathrm{~m}$ elev.), caught manually, 06.iii.2014, P.B. Gervazoni leg., [CARTROUNNE 6665, 11 females; CARTROUNNE 6666, 8 males]. Argentina: Corrientes: city of Corrientes: Barrio Universitario $\left(27^{\circ} 27^{\prime} 51^{\prime \prime} \mathrm{S}, 058^{\circ} 46^{\prime} 51^{\prime \prime} \mathrm{W}, 52 \mathrm{~m}\right.$ elev.), caught manually 02.iii.2014, P.B. Gervazoni leg, [CARTROUNNE 6667, 27 females; CARTROUNNE 6668, 2 males; CARTROUNNE 6669, 32 females; CARTROUNNE 6670, 1 male; CARTROUNNE 6671, 1 male; CARTROUNNE 6672, 1 male; CARTROUNNE 6673, 1 male; CARTROUNNE 6674, 1 male].

Identification. To facilitate the identification of C. maculata, female body coloration and some external morphological characters of males (Fig. 1) are given below. The information is based on Boucek and Delvare (1992).

Female body size 5.5-6 mm. Scape and pedicel yellowish, flagellum brownish; body yellow with some parts black: an inverted V on the antennal scrobes (Fig. 1C); a median line between lateral and occipital ocelli; a median line on pronotal collum; a macula above occipital foramen (Fig. 1D); mesoscutal mid lobe also with a black part just behind posterior edge of pronotum; central small spots on each mesoscutal lateral lobes (Fig. 1D); transscutal line, mesoscutal mid lobe, median line on scutellum (Fig. 1C, D), and on mesopleuron anterior (Fig. 1C); mesopleuron with a small spot on the femoral scrobe (Fig. 1A, B), hind coxa with 2 spots, 1 proximal and dorsal, other at apex; hind trochanter and hind femur with a small spot apically, all teeth of hind femur and ovipositor sheaths; tergites 1 to 5 with transverse dorsal stripes.

Males present smaller body sizes than females, with a mean length of $4.5 \mathrm{~mm}$. Antenna generally completely yellowish; scape hardly widening towards apex, with sensilar area hardly visible, pedicel not modified, clava area with sutures slightly oblique and, rounded at apex; striae of mesoscutum better developed than in female; hind coxa with a complete longitudinal strip ventrally; petiole only slightly longer than in female (Boucek and Delvare 1992).

\section{Discussion}

Conura maculata is not included among the species of Conura reported for Argentina by Boucek and Delvare (1992), De Santis and Fidalgo (1994), and Arias and 


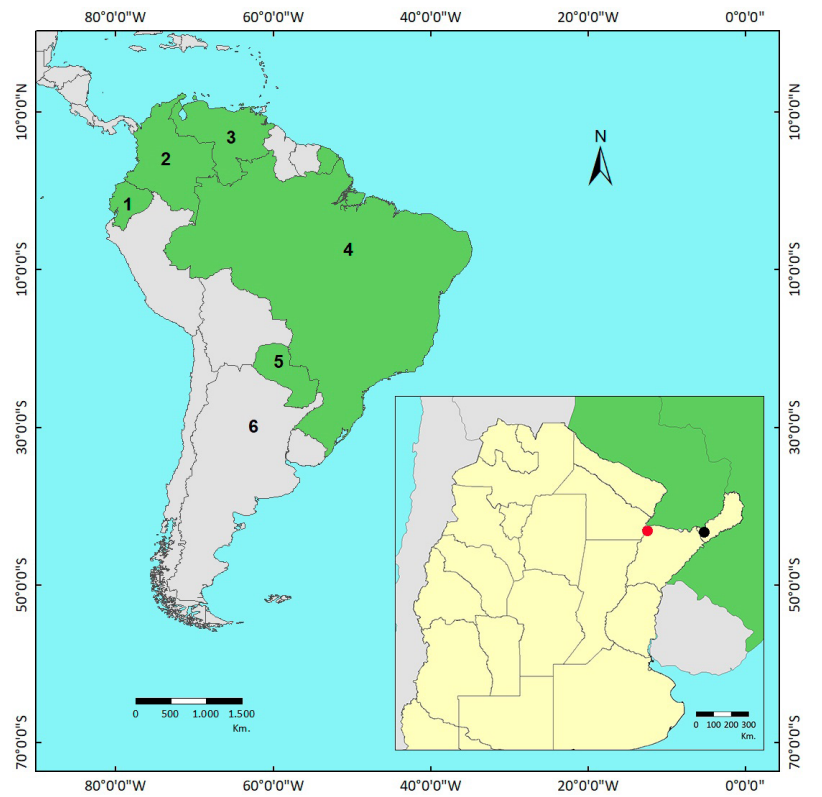

Figure 3. Geographic distribution of Conura maculata in South America: 1 = Ecuador, 2 = Colombia, $3=$ Venezuela, $4=$ Brazil, $5=$ Paraguay, $6=$ Argentina) and in Argentina (inset). Black dot represents the previously known record (Misiones) and red dot represents the new record (Corrientes).

Delvare (2003). However, De Santis (1989) reported it at Santa Inés, Posadas city in the Misiones province and Noyes (2017) includes Argentina in its distribution area, but did not provide a specific locality (Fig 3).

With our discovery of chysalids of $O$. invirae amplificatus parasitized by C. maculata in the city of Corrientes, we report C. maculata from the province for the first time. Our record is also only the second time that this species has been found in Argentina, and expands the geographical distribution of this parasitoid wasp west in the country from the previous Argentine record. The parasitoid-host interaction between $O$. invirae amplificatus and C. maculata is the first such report for Argentina.

\section{Acknowledgements}

We thank Dr Gerard Delvare, Centre de Coopération Internationale en Recherche Agronomique pour le Développement, Montpellier, France, for his assistance for parasitoid identification and Dr Patricio Fidalgo, Centro Regional de Investigaciones Científicas y Transferencia Tecnológica de La Rioja for the bibliography provided.

\section{Authors' Contributions}

PBG and MOA identified the specimens and wrote the text; PBG collected and photographed the specimens and produced the map.

\section{References}

Arias DC, Delvare G (2003) Lista de los géneros y especies de la familia Chalcididae (Hymenoptera: Chalcidoidea) de la región Neotropical. Biota Colombiana 4 (2): 123-145. https://doi.org/10.21068/ bc.v4i2.129
Boucek Z, Delvare G (1992) The identities of species described or classified under Chalcis by J.C. Fabricius. In: Delvare G, Boucek Z (Eds) On the New World Chalcididae (Hymenoptera). Memoirs of the American Entomological Institute 53:11-48.

Bristow CR (1991) A revision of the brassoline genus Opsiphanes (Lepidoptera: Rhopalocera). Zoological Journal of the Linnean Society 101 (3): 203-293.

Canals GR (2003) Mariposas de misiones. LOLA, Literature of Latin America, Buenos Aires, 476 pp.

Couri MS, Tavares MT, Stenzel RR (2006) Parasitoidism of chalcidid waps (Hymenoptera, Chalcididae) on Philornis sp. (Diptera, Muscidae). Brazilian Journal of Biology 66: 553-557. https://doi.org/ 10.1590/S1519-69842006000300022

De Santis L, Fidalgo P (1994) Catálogo de himenópteros calcidoideos de América al Sur de Estados Unidos. Serie de la Academia Nacional de Agronomía y Veterinaria 13: 1-154.

De Santis L (1989) Catálogo de los himenópteros calcidoideos de América al Sur de los Estados Unidos. Segundo suplemento. Acta Entomológica Chilena 15: 9-90.

Delvare G, Arias Penna DC (2006) Família Chalcididae. In: Fernández F, Sharkey MJ (Eds) Introducción a los Hymenoptera de la región Neotropical. Sociedad Colombiana de Entomologia y Universidad Nacional de Colombia, Bogotá, 647-660.

Delvare G, Bouceek Z (1992) On the new world Chalcididae (Hymenoptera). Memoirs of the American Entomological Institute 53: 1-466.

Fabricius JC (1787) Mantissa Insectorum: Sistens Eorvm Species Nvper Detectas. Adiectis Synonymis, Observationibvs, Descriptionibvs, Emendationibvs. Proft, Hafniae, 382 pp.

Ferreira J, Teodoro A, Negrisoli JAS, Guzzo E. (2015) Descrição, bioecologia e manejo das lagartas-do-coqueiro Brassolis Sophorae L. e Opsiphanes invirae H.(Lepidoptera: Nymphalidae). Comunicado Técnico, Embrapa Tabuleiros Costeiros 178: 1-8. http:// www.infoteca.cnptia.embrapa.br/infoteca/handle/doc/1042908. Accessed on: 2018-9-29.

Gates MW, Lill JT, Kula RR, O’hara JE, Wahl DB, Smith DR, Whitfield JB, Murphy SM, Stoeple TM (2012) Review of parasitoid wasps and flies (Hymenoptera, Diptera) associated with Limacodidae (Lepidoptera) in North America. Proceedings of the Entomological Society of Washington 114 (1): 24-110. https://doi. org/10.4289/0013-8797.114.1.24

Gibson GAP (1993) Superfamilies Mymarommatoidea and Chalcicoidea. In: Goulet H, Huber JT, (Eds) Hymenoptera of the World: An Identification Guide to Families. Research Branch, Agriculture Canada, Ottawa, 570-655.

Hayward KJ (1973) Catálogo de los ropalóceros argentinos. Imprenta de la Universidad Nacional de Tucumán, Tucumán, 318 pp.

Hubner J [1808] Sammlung exotischer Schmetterlinge, 1 [published 1806-1819]; Geyer, Augsburg, 32 pp.

Marchiori CH, Silva CG, Lobo AP (2004) Parasitoids of Tuta absoluta (Meyrick, 1917) (Lepidoptera: Gelechiidae) collected on tomato plants in Lavras, state of Minas Gerais, Brazil. Brazilian Journal of Biology 64 (3A): 551-552. https://doi.org/10.1590/S151969842004000300018

Marcicano MDL, Lima IMM, Tavares MT, Casagrande MM (2007) Parasitism of Brassolis sophorae laurentii Stichel (Lepidoptera: Nymphalidae, Brassolinae) pupae by Conura morleyi (Ashmead) (Hymenoptera: Chalcididae, Chalcidini), in the state of Alagoas, Brazil. Neotropical Entomology 36 (4): 629-631 https://doi.org/ 10.1590/S1519-566X2007000400026

Márquez F, Florentino J (2007) Palmeras porteñas. Fabio Márquez, Colección Azulejo, Programa Biodiversidad Urbana, Buenos Aires, 56 pp.

Montes SMN, Costa VA (2011) Parasitismo de huevos de Paraselenis flava (Coleoptera: Chrysomelidae) en batata (Ipomoea batatas). Revista Colombiana de Entomologia 37 (2): 249-251.

Nájera M, Souza YB (2010) Insectos benéficos: guía para su identificación. Instituto Nacional de Investigaciones Forestales Agrícolas y Pecuarias, México, 72 pp. 
Noyes JS (2017) Universal Chalcidoidea Database. http://www.nhm. ac.uk/research-curation/research/projects/chalcidoids/. Accessed on: 2018-08-08.

Núñez Bustos E (2008) Las especies urbanas de Rhopalocera de la Reserva Ecológica Costanera Sur, Ciudad de Buenos Aires, Argentina (Lepidoptera: Hesperioidea y Papilionoidea). SHILAP Revista de Lepidopterología 36 (144): 435-447.

Pastrana JA, Braun K (2004) Los lepidópteros argentinos: sus plantas hospedadoras y otros sustratos alimenticios. Sociedad Entomológica Argentina, San Miguel de Tucumán, 334 pp.

Pulido FJ, Cardenas MR (1979) Biología del gusano cabra de las hojas del plátano Opsiphanes envirae Hubner (Lepidoptera: Brassolidae). Revista Colombiana de Entomologia 5 (3-4): 45-51.

Sakazaki AY, Ribeiro RC, Tinôco RS, Lemos WDP, Zanuncio JC (2011) Registro de espécies de Conura spp., parasitoides e hiperparasitóides em insetos praga em cultivos da palma do óleo na região Amazônica. Anais de resumos expandidos III. Simpósio Brasileiro de Agropecuária Sustentável, Viçosa, Minas Gerais, 429-431.

Salgado-Neto G, Lopes-da-Silva M (2011) First report of parasitism on pupae of Opsiphanes invirae amplificatus Stichel (Lepidop- tera, Nymphalidae) by Conura (Conura) maculata (Fabricius) (Hymenoptera, Chalcididae) in Rio Grande do Sul, Brazil. Revista Brasileira de Entomologia 55 (2): 85-286. https://doi.org/10.1590/ S0085-56262011005000016

Salgado-Neto G (2008) Aspectos da biologia de parasitóides Hymenoptera e Diptera associados à Brassolis astyra Godart, 1824 e a Opsiphanes invirae amplificatus Stichel (1904) (Lepidoptera: Morphinae). Master's theses, Universidade Federal de Santa María, Santa María, 110 pp.

Stichel H (1904) Lepidoptera, Rhopalocera, Fam. Nymphalidae, Subfm. Brassolinae. In: Wytsman P (Ed) Genera Insectorum, 20, Verteneuil V, Desmet L Imprimeurs-Éditeurs. Brüssel, 1-48.

Stireman JO, Singer MS (2003) What determines host range in parasitoids? An analysis of a tachinid parasitoid community. Oecologia 135 (4): 629-638. https://doi.org/10.1007/s00442-003-1235-2

Tibcherani M, Aranda R, Mello RL (2016) First record of Conura morleyi (Ashmead, 1904) (Hymenoptera: Chalcididae) parasitizing Brassolis sp. (Lepidoptera: Nymphalidae) for Mato Grosso do Sul, Brazil. Check List 12 (5): 1981. https://doi. org/10.15560/12.5.1981 